pockets of elementary virus particles are present in the cytoplasm-not unlike some of the inclusions shown by Dr. Lépine. Vaccinia-infected chorioallantoic membrane, on the other hand, shows some peripheral protrusions in addition to the characteristic brick-shaped particles inside the infected cells. Early in the course of infection a few virus particles are present; but again no small or dividing forms can be seen. In a few cases, chains of particles of standard size can be seen. Pictures of bacteriophage suggest the separate formation of tails and empty heads at an early stage in 'phage production. These appear to arise de novo in the host cytoplasm, that is, unassociated with parent particles.

Mr. F. C. Bawden (Harpenden) defined virus as a name for the cause of a transmissible disease with no visible cause. What is studied in the laboratory is a fraction which contains the maximal infectivity in the minimal of chemical substance. In the 1930's the study of the plant viruses was carried out mainly by chemical isolations. Twelve viruses have been isolated in a state of homogeneity, and in pure chemical form all are ribonucleoproteins. They differ among themselves in the ratio of protein to nucleic acid, and electron microscopy has shown differences in morphology. The nucleoprotein appears to be the essential multiplying portion of the virus; but in studying chemically purified fractions it is well to remember that much may have been lost in the purification processes. He reminded the audience, in this connexion, that the removal of a rabbit's ear or tail would be unlikely to affect its reproductive activity.

Mr. Bawden referred to the dark period following infection, when little or no virus is detectable in the cells, and which led him to favour the hypothesis that the virus changes the genetic character of its host. In the course of infection a number of other types of particle are produced besides virus; these have been variously named 'incomplete virus', soluble antigens, etc. No kind of particle has been shown to be the forerunner of any other type, and Mr. Bawden thought it was asking a lot of Nature to turn out millions of particles identical with one another.

In the lively discussion which followed, a great deal of interest was shown in the recent demonstration by Hershey and Chase that, following infection by bacteriophage, the protein shell of the infecting 'phage remains outside the infected bacterial cell, while the nucleic acid enters and is able to initiate virus production even if the protein shells are removed by shearing forces. Dr. R. Markham, in particular, said he was mystified as to how 'phage nucleic acid got into and out of its protein shell and whether the results would apply to other viruses. In a meeting where many interesting points were discussed, this topic seemed to appeal most to the general imagination.

Prof. S. P. Bedson pointed to an inconsistency in the argument about how viruses multiply. It is generally conceded that the rickettsiæ and the organisms (? viruses) of the psittacosis group multiply by binary fission; but a different form of multiplication is postulated for the smaller viruses. The main argument in favour of this hypothesis is that following infection of cells by one of the smaller viruses, there is a latent period during which little or no virus can be detected in the cells, followed by a sudden increase in the amount of detectable virus. However, recent experimental work indicates that organisms of the psittacosis group, large viruses such as those of myxoma and vaccinia, and indeed all viruses which have been studied, show a similar type of growth curve. Prof. Bedson argued that if psittacosis organisms multiplied by binary fission, there was no real reason why smaller viruses should not do so also, and the speakers were not prepared to dispute his argument.

Prof. Wilson Smith was sceptical of generalizations in the field of viruses and put forward some experimental evidence with the proviso that, so far as he knew, it applied to influenza virus and nothing else. In general, his evidence lent support to Dr. Wyckoff's view that the virus incorporated some part of the host cytoplasm in it. Heat-treated influenza $A$ virus crosses serologically with the $B$ virus, and the implication is that both forms have something in common derived from the host, or are contaminated by host protein. On the whole he favoured the former. Mr. Bawden countered with the statement that "one man's impurity is very often another man's biologically important product".

Dr. B. Stocker described the work of Zinder and Lederberg on 'phage transduction as supporting Wilson Smith's hypothesis. He pointed out that the factor which is transduced does not appear to be superficially situated on the transducing 'phage. $\mathrm{He}$ also described the behaviour of lysogenic 'phage as evidence that 'phage could be transmitted through different generations of bacteria in the complete absence of the usual structural characteristics.

Dr. A. Isaacs objected to the term fragments of cytoplasm when applied to viruses, and Bawden supported this and pointed to a competition between the cell and the virus for essential constituents.

Dr. McFarlane, in summing up, noted that a major part of the evening had been devoted to considerations of the influence of the host cell on the nature and constitution of the virus. This spontaneous trend, he said, suggests that the matter is of prime importance. Some speakers were prepared to go so far as to say that virus particles are shaped out of pieces of host cytoplasm-possibly out of whole genetic units-while others would only say that molecules with the specific antigenic configuration of the host are incorporated into viruses. A less vocal section of the audience appeared to resent these views and could see few grounds for believing that infecting virus particles did more than borrow some biochemical mechanisms from the host and get on with the job of self-duplication. Dr. McFarlane also remarked on the fact that the crystallographers present were prepared to confer 'crystal' status on the insect polyhedral bodies although these contained only a few per cent of virus. It seemed, therefore, that after crystals are isolated, the search must still go on for the ultimate virus particles.

\section{THE MUSEUMS ASSOCIATION ANNUAL CONFERENCE AT YORK}

$\mathrm{T}$ HE fifty-ninth annual conference of the Museums Association was held at York during June 22-26 under the presidency of Dr. F. J. North, of the National Museum of Wales. It was on May 3, 1888, that museum curators from all parts of Britain were called by the Yorkshire Philosophical Society to discuss matters of common interest; and a further meeting, also at York, on June 20, 1899, witnessed the formation of the Museums Association. 
The Conference was attended by about 330 delegates of whom eleven were from overseas. Except for the presidential address and the papers describing the policy and collections in the four museums in York, the theme centred about "Museums and the Public". The main subject for discussion was the methods of display or presentation for the various kinds of museum and art gallery material. The Conference early admitted that there have been radical changes in recent years, and lively discussion ensued as to whether the so-called 'shop-window technique' had not been over-stressed. Quite wide differences of opinion were also expressed regarding what should be shown in the exhibition cases. It was evident that scientific advances and new materials offer new solutions to the practical problems of exhibition, but that these are not without their dangers if attempted by those without adequate training.

Dr. North, in his presidential address, endeavoured to answer the questions: "Why Museums and Wherefore the Museums Association ?". He felt that the irreplaceable contribution of museums is in their power to enable us to recapture the capacity to wonder. $\mathrm{He}$ also maintained that our understanding and enjoyment of common things can be greatly enhanced by what museums have to tell us about them. Museums can inspire a lively curiosity about the works of Nature and man, and provide a potential antidote to boredom, one of the greatest evils of modern life. Although by its articles of association the Association is precluded from trade union activities, it can advance the interest of its members and help them to render even better service to the community. The Journal and the annual conference provide for the interchange of views and the pooling of experience, while the diploma and training schemes seek to establish a recognized professional status.

Among the specialized papers, Dr. Mary Woodall (Birmingham) dealt with the display of paintings, and Mr. Ian Finlay (Edinburgh) with the display of other art objects. The former paper produced a lively discussion concerning the advisability or otherwise of glazing paintings. Although this is a difficult problem in which many factors must be considered, the balance of opinion veered to the elimination of glass protection. Dr. Woodall also advocated the use of small intimate rooms as well as the lofty and pompous galleries, and preferred textiles for background rather than distempered or painted walls.

Mr. H. Stansfield (Liverpool) described the difficulties of an effective display for botanical material and emphasized the importance of showing living specimens. He also stressed that there is more value in discovering new facts about common plants than in merely pointing out a rare one. He stated that illuminated dioramas can be used to link plants of the past with those of the present day, and advocated the presentation of the economic aspects of botany.

Mr. A. J. Butler (Geological Museum, London) said that it is possible to present geology to the public in a manner which gives pleasure to the emotions and the intellect; it is not a fusty academic discipline. Dioramas showing present scenery and reconstructions of the past, coloured relief models and photographic exposition have already proved their worth. Mr. Butler visualized an extended use of coloured photographic prints and colour films of scenery, and of the international exchange of special photographic exhibits dealing with areas famous for their geology.

Mr. A. Hazelwood (Bolton) suggested an introductory exhibit in zoology illustrating the terms used in classification. $\mathrm{He}$ advocated modified habitat groups in which the display is produced with the minimum of scenic distraction and the use of plasticembedded specimens displayed together with enlarged models.

Dr. Iorworth C. Peate (Welsh Folk Museums, St. Fagans) maintained that a folk museum should represent the natural setting and environment of the life portrayed through the exhibits. It should have a museum building for the systematic display of material and act as a centre for archives and research. It should also contain a lecture theatre for activities illustrating national or regional life. Around the folk museum should be displayed old buildings which have been carefully removed from their original sites and furnished as complete exhibits portraying the normal life of the particular period.

At the annual general meeting, the Association established the 'technical certificate' which will be awarded only to those who attain the required degree of proficiency and will provide official recognition for those who work in museum laboratories and workshops. It will be complementary to the diploma of the Association, which was established twenty years ago as the professional qualification for the administrative and curatorial staff.

At the same meeting the Museums Association Benevolent Fund was launched, the purpose of which is to help members and their dependants in financial difficulties in a profession that with few exceptions is inadequately paid.

Sir Leigh Ashton (Victoria and Albert Museum, London) was elected president for 1953-54, and the next annual conference will be held in Edinburgh during July 19-23, 1954.

\section{INTERNATIONAL RADIO CONSULTATIVE COMMITTEE}

\section{FORTHCOMING PLENARY ASSEMBLY IN LONDON}

$T$ HE seventh plenary assembly of the International Radio Consultative Committee (C.C.I.R.) will be held in London during September 3-October 7, inclusive. This assembly will discuss various technical problems encountered in the practice and development of radio communication, with the view of making recommendations to be submitted to the International Telecommunications Union (I.T.U.). The previous plenary assembly was held in Geneva in 1951; but three of the study groups of the Committee met in Stockholm in 1952 in order to give technical advice and assistance in the assignment of very high frequencies for broadcasting and television services in Europe (see Nature, 170, 185; 1952).

The work of the Committee is organized under fourteen study groups, the chairmen and fields of activity of which are as follow's: (I) Dr. Ernst Metzler (Switzerland), transmitters ; (II) M. Pierre David (France), receivers ; (III) Dr. H. C. A. van Duuren (Netherlands), complete radio systems used by the different services ; (IV) Prof. I. Sacco (Italy), ground-wave propagation; (V) Dr. R. L. Smith-Rose 